\title{
G×E Interaction for Seed Yield and Its Components Traits in Summer Sesame (Sesamum indicum L)
}

\author{
R.S. Parmar $^{1^{*}}$, V.P. Chovatia ${ }^{2}$, H.R. Barad ${ }^{3}$, G.K. Sapara ${ }^{4}$ and Rajivkumar ${ }^{5}$ \\ ${ }^{1}$ College of Agriculture, Junagadh Agricultural University, Motabhandariya (Amreli)-355610, \\ Gujarat, India \\ ${ }^{2}$ Junagadh Agricultural University, Junagadh, Gujarat, India \\ ${ }^{3}$ Agriculture officer, Registrar office, Junagadh Agricultural University, Junagadh, India \\ ${ }^{4}$ Main Oil Seed Research Station, ${ }^{5}$ Department of Genetics \& Plant Breeding, \\ JAU, Junagadh, India \\ *Corresponding author
}

\section{A B S T R A C T}

The present investigation Ph.D thesis entitled "Genetics architecture of seed yield and its components in sesame (sesamum indicum L.) over environments" was conducted at the Agricultural Research Station, J.A.U., Amreli and Department of Seed Science and Technology, College of Agriculture, Sagadividi Farm, J.A.U., Junagadh, Gujarat. These 56

\section{Keywords}

Sesame, GxE interaction, Regression coefficient, Stability analysis

Article Info

Accepted:

15 November 2018

Available Online:

10 December 2018 genotypes along with a two checks, G.Til-2 and G.Til-3 were evaluated in a four environments were created through different time and location for sowing during summer 2016. The stability analysis indicated the presence of $\mathrm{G} \times \mathrm{E}$ interaction were found significant for all the characters when tested against pooled error excepts days to flowering, days to maturity, width of capsule and number of capsule per leaf axil. The mean squares due to $E+(G \times E)$ were significant when tested against the pooled error for all the characters. In this direction, two hybrids AT-322 x G.Til-10 and AT-319 x AT-285 had below average stability which well adapted to favourable environments. The parents, AT-319 for length of capsule, G.Til-3 for width of capsule, AT-319 for number of capsule per plant, IS-209 for number of seed per capsule, G.Til-1 for 1000 seed weight and G.Til-3 for seed yield per plant were found average stable for environments.. Check. Bhuva-2 x G.Til-10 ( $\bar{X}=6.49$ ) had greater tolerance to environmental changes and thereby this hybrids would had specific adaptability to poor yielding environments. Hence, these parents may be used in the breeding programmes aimed at improving seed yield and yield components, in addition to incorporation of phenotypic stability for the traits in sesame.

\section{Introduction}

Sesame (Sesamum indicum L.), commonly known as gingelly, til, benniseed, simsim, til or tal is a member of the order Tubiflorae and family Pedaliaceae. Sesame is predominantly annual self-pollinated (85- 95\%) diploid $(2 n=2 x=26)$ crop. It is referred as 'Queen of Oilseeds' due to its regard by the users and owing to its oil quality (Bedigian and Harlan 1986). It is one of the most ancient crops in the world known to mankind, with 
archeological evidences dating back to 2250 and $1750 \mathrm{BC}$ at Harappa in the Indus valley (Najeeb et al., 2012). Its oil was extracted by the ancient Hindus, which was used for certain ritual purposes (Weiss, 1983). Ironically, it is considered as an 'orphan crop' due to meager research efforts attributed to the fact that it is not a mandate crop for any international crop research institute (Bhat et al., 1999). Sesame is an important annual oilseed crop in the tropics and warm subtropics. At present, Myanmar is the largest producer of sesame seed in the world followed by India, China, Ethiopia, Nigeria and Uganda. In India, during 2015-16, sesame is cultivated in an area of 17.46 lakh ha with a production of 9.11 lakh tones annually and productivity of $474 \mathrm{~kg} / \mathrm{ha}$ (Anon., 2016). Being the fourth important oilseed crop in Indian agriculture after groundnut, rape seed and mustard, it is widely cultivated in the states of Uttar Pradesh, Rajasthan, Orissa, Gujarat, Andhra Pradesh, Tamil Nadu, Karnataka, West Bengal, Bihar and Assam. In Gujarat, during 2015-16, sesame is cultivated in an area of 2.56 lakh ha with a production of 1.52 lakh tones and productivity of $530 \mathrm{~kg} / \mathrm{ha}$ (Anon., 2016). This crop is generally cultivated as sole or mixed crop during kharif, semi-rabi and summer season. The productivity of sesame is very low as compared to other oilseeds hence, it is necessary to raise the productivity and thereby total oilseeds production in order to meet edible oil requirement of the country.

The development of cultivars, which can be recommended to a wide range of diversified environments, is the ultimate goal of the plant breeders in a crop improvement programme. The adaptation of a cultivar over different environments is usually tested by the level of its interaction with different environments under which it is cultivated. A variety or genotype is considered to be more adaptive or stable one, if it has a high mean yield but a low degree of variation in yielding ability when grown over varied environments.
Phenotypic expression of quantitative characters is highly influenced by environmental fluctuations. $\mathrm{G} \times \mathrm{E}$ interaction, depending upon their nature and magnitude, leads to bias in the estimates of gene effects and combining ability for various characters sensitive to environmental modulations. Such traits are less amenable to selection. It is, therefore, necessary to assess the sensitivity of estimates of gene effects under variable environmental conditions so as to ensure better prediction and genetic gain under selection. Present study deals with such an endeavours.

An assessment of the $\mathrm{G} \times \mathrm{E}$ interaction in crop breeding programme is of paramount importance for the identification of genotypes with wider adaptability. The nature and importance of magnitude and pattern of $\mathrm{G} \times \mathrm{E}$ interaction have been discussed in detail by Comstock and Moll (1963) and Allard and Bradshaw (1964) in different field crops and several methods have been proposed to evaluate stability. In the present investigation, the most widely adopted statistical model for stability analysis as suggested by Eberhart and Russell (1966) was used to assess the G x E interactions and draw valid conclusions regarding the stability of sesame genotypes (parents and hybrids) for seed yield and yield contributing attributes.

Environment plays an important role in the final phenotypic expression of a character. A genotype is known to show a differential phenotypic response in development when introduced in different environments. The genotype $\mathrm{x}$ environment $(\mathrm{G} \times \mathrm{E})$ interaction is particularly important in the expression of quantitative characters, which are controlled by polygenic systems and are greatly modified by the environmental influences. A knowledge of the nature and relative magnitude of the various types of $\mathrm{G} \times \mathrm{E}$ interaction is useful in making decisions concerning breeding 
methods, selection programmes and testing procedures in crop plants. Finlay and Wilkinson (1963) considered linear regression as a measure of stability. Eberhart and Russell (1966) emphasized the need of considering both linear $\left(b_{I}=\right.$ regression coefficient $)$ and non-linear $\left(\mathrm{S}^{2} \mathrm{~d}_{\mathrm{i}}=\right.$ deviation from regression) components of $\mathrm{G} \times \mathrm{E}$ interaction in judging the phenotypic stability of a variety. Later on, Breese (1969), Samuel et al., (1970) and Paroda and Hayes (1971) suggested that linear regression (bi) should be regarded as measure of response of a particular genotype, whereas, the deviation from regression $\left(\mathrm{S}^{2} \mathrm{di}\right)$ as measure of stability.

In India, sesame is grown under diverse agroclimatic conditions, which resulted in fluctuation for its production. Varietal adaptation to environmental fluctuations is important for stabilization of sesame production. The study of $\mathrm{G} \times \mathrm{E}$ interactions leads to meaningful evaluation of individual genotype for seed yield and its components, which could be used in future breeding programme. The present investigation was, therefore, undertaken to study Genotype $\mathrm{x}$ Environment interaction for seed yield and its components in (14 parents +2 checks +40 crosses) grown under four different environments (created by two dates of sowing at two locations).

\section{Materials and Methods}

My Ph.D theisis experimental material comprised of four females as testers viz., AT285, G.Til-1, G.Til-10 and RT-54 and ten males as lines namely AT-253, AT-265, AT306, AT-307, AT-319, AT-322, AT-341, Bhuva-2, Khadkala-S and IS-209 and their 40 hybrids derived from line $\mathrm{x}$ tester mating design. These 56 genotypes along with a two checks, G.Til-2 and G.Til-3 were evaluated in a four environments were created through different time and location for sowing during summer 2016 i.e., $\mathrm{E}_{1}=$ Timely sowing $3^{\text {rd }}$ week of February at Amreli (20 ${ }^{\text {th }}$ February), $\mathrm{E}_{2}=$ Timely sowing $3^{\text {rd }}$ week of February at Junagadh $\left(20^{\text {th }}\right.$ February $), E_{3}=$ Late sowing $2^{\text {nd }}$ week of March at Amreli $\left(10^{\text {th }}\right.$ March), and $\mathrm{E}_{4}=$ Late sowing $2^{\text {nd }}$ week of March at Junagadh $\left(10^{\text {th }}\right.$ March $)$. The parents and $\mathrm{F}_{1}$ 's with checks were sown in single row (plot) of $2.25 \mathrm{~m}$ length with spacing $45 \mathrm{~cm} \times 15 \mathrm{~cm}$. All the agronomical practices and plant protection measures were followed as and when required to raise a good crop of sesame. The observations were recorded on five randomly selected plants from parents and crosses for all characters viz., days to flowering, days to maturity, plant height $(\mathrm{cm})$, height to first capsule $(\mathrm{cm})$, number of branches per plant, number of internodes per plant, length of capsule $(\mathrm{cm})$, width of capsule $(\mathrm{cm})$, number of capsules per plant, number of capsules per leaf axil, number of seeds per capsule, 100-seed weight (g) and seed yield per plant (g).Agricultural Research Station, J.A.U., Amreli is located in North Saurashtra Agro-climatic zone-VI of Gujarat state. Geographically, Amreli is situated at $21.35 \mathrm{~N}$ latitude and $71.12 \mathrm{E}$ longitudes with an elevation of 130 meters above the mean sea level. The soil of the experimental site was medium black with $\mathrm{pH}$ is 7.5 to 8.3 .

Deptt. Seed Science and Technology, Sagadividi Farm, J.A.U. Junagadh is located in South Saurashtra Agro Climatic Zone-III of Gujarat state. Geographically, Junagadh is situated at $21.50 \mathrm{~N}$ latitude and $70.50 \mathrm{E}$ longitudes with an elevation of 82.92 meters above the mean sea level. The soil of the experimental site was medium black with $\mathrm{pH}$ 7.8. Standard procedures for analysis of variance were followed. Data were first subjected to the analysis followed for randomized block design as per Panse and Sukhatme (1967). Stability analysis was carried out following Eberhart and Russel (1966). Estimates of mean performance (x), 
regression coefficient (bi) and deviations from regression $\left(S^{2}\right.$ di) were used to draw inferences on stability of genotypes.

\section{Results and Discussion}

The stability analysis indicated the presence of genotype $\mathrm{x}$ environment $(\mathrm{G} \times \mathrm{E}$ ) interaction were found significant for all the characters when tested against pooled error excepts days to flowering, days to maturity, width of capsule and number of capsule per leaf axil The mean squares due to $\mathrm{E}+(\mathrm{G} \times \mathrm{E})$ were significant when tested against the pooled error for all the characters. A very high proportion of total variance was accounted for the environment (linear) component (Table 1). Higher magnitude of mean square due to environment (linear) indicated that differences between environments were considerable for all the characters and revealed that these characters were influenced by environments considerably, suggesting thereby that large differences between environments alongwith the greater part of genotypic response was a linear function of environments. This indicated that environments created by various sowing dates at two locations were justified and had linear effect. These results are in agreement with the earlier findings of Kumaresan and Nadarajan (2010), Kumar et al., (2013), Chaudhari et al., (2015), Mali et al., (2015), Khan et al., (2015), Patil et al., (2015), Raikwar (2016) and Ram et al., (2018). The portioning of $\mathrm{E}+(\mathrm{G} \times \mathrm{E})$ mean square into three components i) environments (linear), (ii) $\mathrm{G} \times \mathrm{E}$ (linear) and (iii) pooled deviation ( $\mathrm{G} \times \mathrm{E}$; non-linear) indicated that the mean squares due to environments (linear) differed significantly and were quite diverse with regards to their effect on performance of the genotypes for seed yield per plant and yield components. Further, the higher magnitude of mean squares due to environments (linear) as compared to $\mathrm{G} \times \mathrm{E}$ (linear) indicated that linear response of environments accounted for the major part of total variation for majority of the characters studied. Both linear and non-linear components of $\mathrm{G} \times \mathrm{E}$ interaction were significant for all the characters which suggested that predictable as well as unpredictable components contributed towards differences in stability of different genotypes. However, magnitude of linear components of $\mathrm{G} \times \mathrm{E}$ was higher as compared to the nonlinear component, which indicated that prediction of performance over environments was still possible for these characters. Linear component of $G \quad x \quad E$ interaction was significant for all characters, which indicated that predictable component contributed towards the differences in stability of genotypes and prediction of performance would be easy for such character. Similar findings were obtained for different characters by Suvarna et al., (2011), Kumar et al., (2013), Chaudhari et al., (2015), Mali et al., (2015), Patil et al., (2015), Raikwar (2016) and Ram et al., (2018).

Eberhart and Russell (1966) emphasized the need of considering both linear regression coefficient (bi) and non-linear, i.e. deviation from regression $\left(S^{2} \mathrm{di}\right)$ components of $\mathrm{G} \times \mathrm{E}$ interactions in measuring the stability of genotypes. Linear regression could be simply regarded as a measure of response of particular genotype, whereas the deviation from regression as the measure of stability (Paroda and Hayes 1971 and Jatsara and Paroda 1980). The genotypes with lowest deviation around regression line $\left(\mathrm{S}^{2} \mathrm{di}\right)$ were considered to be stable and vice-versa. Along with above measures, the high mean performance was also considered as a requirement for identifying high yield and stable genotypes. Thus, in present investigation three measures, viz. higher mean performance, regression coefficient $(b i=1)$ and deviation from regression $\left(\mathrm{S}^{2} \mathrm{di}=0\right)$ were used to identify superior and stable genotypes. 
The estimates of stability parameters for characters presented (Table 2) revealed for seed yield per plant in which check G.Til-3 $(\bar{X}=7.10)$ had for average stability which showed average responsive. None of parent possesses with high mean for average stability but with lower mean showed in males AT-322 $(\overline{\mathrm{X}}=3.54)$ which showed widely adaptable to different environments. Two hybrids namely AT-322 x G.Til-10 ( $\overline{\mathrm{X}}=8.73)$ and AT-319 x AT-285 ( $\bar{X}=6.73)$ had below average stability. For average stability none of hybrid found stable over environment with high yield mean. For above average stability Bhuva- $2 \mathrm{x}$ G.Til-10 ( $\overline{\mathrm{X}}=6.49)$ had greater tolerance to environmental. In days to flowering the parent Khadkala-S $(\bar{X}=37.08)$ had below average stability and specifically adapted to favourable environments. The parent AT-319 ( $\overline{\mathrm{X}}=$ 37.50), AT-341 ( $\bar{X}=39.33$ ) and check G.Til-3 ( $\bar{X}=38.67$ ) had early flowering with less than unit regression coefficient) and non-significant deviation from regression, which indicated above average. Top five hybrids viz., Bhuva-2 $x$ AT-285 ( $\overline{\mathrm{X}}=36.75)$, Bhuva-2 x RT-54 ( $\overline{\mathrm{X}}=37.33)$, AT-253 x RT-54 ( $\overline{\mathrm{X}}=37.50)$, Khadkala-S x G.Til-1 ( $\bar{X}=38.08)$ and IS-209 $x$ AT-285 ( $\bar{X}=38.08)$ had below average stability. For above average stability Khadkala-S x AT-285 ( $\overline{\mathrm{X}}=36.17)$, AT-306 x G.Til-1 $(\bar{X}=36.42), \quad$ AT-265 $x \quad$ G.Til-1 ( $\bar{X}=36.37)$, AT-319 x G.Til-1 $(\bar{X}=36.92)$ and AT-341 x RT-54 ( $\bar{X}=37.33)$ were recorded. Twelve hybrids were average responsive to all the environments with late in flowering.

For days to maturity none of male and female parent (including checks) had below average stability and were well adapted to favourable environments; parents IS-209 ( $\overline{\mathrm{X}}=83.08)$ and AT-285 ( $\bar{X}=82.75)$ had above average stability. In hybrids, it was observed that none of hybrids had early maturity with average responsiveness. Out of 12 hybrids, seven hybrids viz., AT-322 x RT-54 ( $\overline{\mathrm{X}}=80.92)$, Bhuva-2 x AT-285 ( $\overline{\mathrm{X}}=81.33)$, AT-265 x AT$285(\bar{X}=81.67)$, AT-306 x RT-54 ( $\bar{X}=82.42)$, AT-307 x RT-54 ( $\bar{X}=82.83)$, Bhuva-2 x RT$54(\bar{X}=82.83)$ and IS-209 $\mathrm{X} \quad$ AT-285 $(\bar{X}=82.92)$ had below stability. Five hybrid namely AT-253 x G.Til-1, AT-265 x G.Til-1, AT-306 x AT-285, AT-319 x G.Til-1, and AT-322 x G.Til-1 above average stability. Out of 40, 18 hybrids recorded as an unpredictable.

In plant height three parents namely G.Til-10 ( $\overline{\mathrm{X}}=81.30)$, Khadkala-S $(\overline{\mathrm{X}}=80.78)$ and AT$285(\bar{X}=67.80)$ had above average. In hybrids, it was observed that one hybrids viz., Bhuva-2 $x \operatorname{AT}-285(\bar{X}=71.16)$ had tall height with average stability. Among five hybrids with high mean, only AT-253 x G.Til-10 $(\overline{\mathrm{X}}=70.36)$ had below average stability and three hybrids IS-209 x G.Til-10 ( $\bar{X}=80.58$ ) AT-306 x RT-54 ( $\overline{\mathrm{X}}=71.34)$ and AT-307 x RT-54 ( $\bar{X}=69.38)$ had above average stability. Out of 40, 30 hybrids considered as an unpredictable. For height to first capsule showed that none of parents had lower height to first capsule with non-significant regression coefficient and non-significant deviation from regression $\left(\mathrm{S}^{2} \mathrm{di}\right)$.Seven parents namely IS$209(\bar{X}=18.88)$, AT-253 ( $\bar{X}=20.98)$, AT-307 $(\bar{X}=21.35), \quad$ AT-265 $\quad(\bar{X}=21.49), \quad$ AT-319 $(\overline{\mathrm{X}}=21.58), \quad$ AT-319 $\quad(\overline{\mathrm{X}}=21.58), \quad$ AT-306 $(\overline{\mathrm{X}}=22.41)$ and AT-307 $(\overline{\mathrm{X}}=23.74)$ and one check G.Til-3 ( $\bar{X}=25.52)$ had above stability 
which suitable for unfavourable environment. One cross AT-341 x RT-54 ( $\overline{\mathrm{X}}=27.09)$ had tall height to first capsule with average responsiveness and was stable across the environments. Among $10 \mathrm{~F}_{1 \mathrm{~S}}$, seven hybrids AT-253 x AT-285 ( $\overline{\mathrm{X}}=17.86)$, AT-322 $\mathrm{x}$ G.Til-1 $\quad(\overline{\mathrm{X}}=20.92), \quad$ AT-341 $\quad \mathrm{x} \quad$ AT-285 ( $\bar{X}=21.54)$, AT-319 x RT-54 ( $\bar{X}=21.93)$, IS$209 \times$ AT-285 ( $\bar{X}=22.01)$, AT-322 x AT-285 $(\bar{X}=22.75)$ and AT-322 $x$ G.Til-10 ( $\bar{X}=25.66)$, had below average stability. Three crosses viz., AT-253 x RT-54 ( $\overline{\mathrm{X}}=18.06)$, AT-265 x AT-285 $(\overline{\mathrm{X}}=18.50)$ and AT-265 x G.Til-1 ( $\bar{X}=24.73$ ) found for above average stability. Among 40 hybrids, 20 hybrids showed as non-linear as an unpredictable.

In number of branches per plant, the check G.Til-3 ( $\overline{\mathrm{X}}=3.04$ ) had below average stability. Among $\mathrm{F}_{1 \mathrm{~S}}$, AT-307 x G.Til-10 ( $\left.\overline{\mathrm{X}}=3.06\right)$ hybrid had high mean with non-significant regression coefficient and non-significant deviation from regression $\left(\mathrm{S}^{2} \mathrm{di}\right)$ and widely adapted to all the environments. Among hybrids, with lower mean four crosses namely Bhuva-2 x G.Til-1 ( $\overline{\mathrm{X}}=2.68)$, AT-319 $\mathrm{x}$ G.Til-1 ( $\overline{\mathrm{X}}=2.65$ ) AT-341 x RT-54 ( $\overline{\mathrm{X}}=2.62$ ) and AT-265 x AT-285 ( $\overline{\mathrm{X}}=2.59)$ and with non-significant regression coefficient $($ bi $\approx 1$ ) and non-significant deviation from regression $\left(\mathrm{S}^{2} \mathrm{di}\right)$. The crosses namely IS-209 x G.Til-10 $(\bar{X}=3.86)$ and AT-307 x G.Til-10 ( $\bar{X}=3.06)$ had below average stability and none of hybrid recorded for above average stability. Among 40 hybrids, 30 hybrids showed as nonlinear as an unpredictable. For number of internodes per plant, parent G.Til-10 ( $\bar{X}=24.89$ ) had below average stability. On the other hand, none of parents recorded above average stability. Among hybrids, IS-209 x G.Til-10 ( $\bar{X}=26.82)$ had more number of branches per plant with non-significant regression coefficient and non-significant deviation from regression $\left(\mathrm{S}^{2} \mathrm{di}\right)$ and widely adaptable over environments. Four hybrids namely Khadkala-S x G.Til-10 ( $\bar{X}=24.56)$, AT-265 x RT-54 ( $\bar{X}=22.68)$, AT-265 x G.Til$10(\overline{\mathrm{X}}=22.15)$ and AT-322 $\mathrm{x}$ AT-285 $(\bar{X}=21.67)$ had below average stability increasing sensitivity to environmental changes and well adapted to favourable environments. AT-341 x G.Til-10 ( $\bar{X}=26.01)$, Bhuva-2 x G.Til-10 ( $\overline{\mathrm{X}}=25.83)$, Bhuva-2 $\mathrm{x}$ AT-285 ( $\bar{X}=24.56), \quad$ AT-322 $x \quad$ G.Til-10 ( $\bar{X}=23.86)$, AT-322 x G.Til-1 $(\bar{X}=23.08)$ and AT-322 x RT-54 ( $\bar{X}=22.39)$ hybrids recorded for above average stability. Among 40 hybrids, 16 hybrids showed as non-linear as an unpredictable.

Length of capsule stated that parents AT-319 ( $\bar{X}=2.80)$ and G.Til-10 ( $\bar{X}=2.66)$ having more length of capsule with non-significant regression coefficient and non-significant deviation from regression $\left(\mathrm{S}^{2} \mathrm{di}\right)$.

Among the parental genotypes, male AT-265 ( $\bar{X}=2.68)$ and check G.Til-3 $(\bar{X}=2.90)$ had below average stability. Among crosses, five crosses viz., AT-253 x G.Til-1 ( $\overline{\mathrm{X}}=2.73$ ), AT$265 \times$ RT-54 ( $\bar{X}=2.62)$, AT -253 x G.Til-10 ( $\overline{\mathrm{X}}=2.54)$ and AT-306 x RT-54 ( $\overline{\mathrm{X}}=2.54)$ had more length of capsule with ( $\mathrm{bi} \approx 1$ ) and nonsignificant $\left(\mathrm{S}^{2} \mathrm{di}\right)$ which showed average stability. Among crosses, two hybrids AT-319 $\mathrm{x}$ G.Til-1( $\overline{\mathrm{X}}=2.65)$ and IS-209 x AT-285 ( $\bar{X}=2.79$ ) had below average stability. Among $40 \mathrm{~F}_{1 \mathrm{~S}}, 29$ hybrids showed as non-linear as an unpredictable. 
Likewise, width of capsule, two males parents viz., AT-285 ( $\overline{\mathrm{X}}=0.80)$ and G.Til- $1(\overline{\mathrm{X}}=0.76)$ had below average stability (bi $>1)$. Check G.Til-3 ( $\overline{\mathrm{X}}=0.78$ ) had average stability (bi=1) and widely adapted to all the environments. Among hybrids, eight hybrids viz., AT-253 x AT-285 ( $\overline{\mathrm{X}}=0.80), \quad$ AT-265 $\quad \mathrm{x} \quad$ G.Til-10 ( $\bar{X}=0.75)$, AT $-306 \times$ G.Til-10 ( $\bar{X}=0.75)$, AT$306 \times$ RT-54 ( $\overline{\mathrm{X}}=0.78)$, AT-319 x G.Til-1 ( $\overline{\mathrm{X}}=0.80)$, AT-319 x RT-54 ( $\overline{\mathrm{X}}=0.77)$, AT$322 \times$ G.Til-1 ( $\overline{\mathrm{X}}=0.78)$ and Khadkala-S $\mathrm{x}$ G.Til-1 ( $\bar{X}=0.79$ ) had below average stability. Four crosses namely AT-265 x G.Til-1 ( $\overline{\mathrm{X}}=0.82)$, AT- $253 \times$ G.Til- $1(\overline{\mathrm{X}}=0.81)$, AT$306 \times$ G.Til-1 $(\overline{\mathrm{X}}=0.76)$ and AT-307 x AT$285(\bar{X}=0.76)$ had average stability. Out of 40, 21 hybrids considered as an unpredictable. In number of capsules per plant, male parent AT-319 ( $\bar{X}=24.25)$ had less number of capsules per plant with non-significant $(\mathrm{bi} \approx 1)$ and non-significant $\left(S^{2} \mathrm{di}\right)$. None of hybrid found for average stability but, IS-209 x AT$285(\bar{X}=22.93)$ had lower mean with nonsignificant $(\mathrm{bi} \approx 1)$ and non-significant $\left(\mathrm{S}^{2} \mathrm{di}\right)$. Among $\mathrm{F}_{1 \mathrm{~S}}$, one hybrid AT-341 x RT-54 $(\bar{X}=34.83)$ had below average stability and one hybrid Bhuva-2 x G.Til-10 ( $\overline{\mathrm{X}}=43.65$ ) had above average stability. Among 40 crosses, 35 hybrids showed as non-linear as an unpredictable.

For number of capsules per leaf axil, male parent IS-209 ( $\overline{\mathrm{X}}=1.37)$ and female parent RT-54 ( $\overline{\mathrm{X}}=1.35$ ) had average stability $(\mathrm{bi}=1)$ and specifically adapted to all the environments. One female parent G.Til-1 ( $\bar{X}=1.3)$ and one check G.Til-3 ( $\bar{X}=1.53)$ had below average stability and were well adapted to favourable environments. Three hybrids
Khadkala-S x AT-285 ( $\overline{\mathrm{X}}=1.73)$, Khadkala-S $x$ G.Til-1 ( $\bar{X}=1.67)$ and AT-265 x AT-285 $(\bar{X}=1.47)$ had stability showing adaptability over varying environments likewise, three hybrids namely AT-265 x RT-54 ( $\overline{\mathrm{X}}=1.35)$. AT-307 x AT-285 ( $\overline{\mathrm{X}}=1.35)$ and AT-322 $\mathrm{x}$ G.Til-1 $(\bar{X}=1.50)$ had below average stability. Two crosses viz., Bhuva-2 x G.Til-1 $(\overline{\mathrm{X}}=1.63)$ and AT-265 x G.Til-1 ( $\bar{X}_{=1.77)}$ showed above average stability. Among 40 crosses, 18 hybrids showed as non-linear as an unpredictable. In number of seeds per capsule for male parent IS-209 ( $\bar{X}=53.81)$ had mean with non-significant and non-significant $\left(\mathrm{S}^{2} \mathrm{di}\right)$, thereby showing general adaptability over varying environments. None of the parent had below average stability and above average stability. For average stability, and for above average stability none of hybrid found with non-significant and non-significant $\left(\mathrm{S}^{2} \mathrm{di}\right)$. Among $\mathrm{F}_{1 \mathrm{~S}}$, two hybrids AT-265 x G.Til-10 $(\bar{X}=56.73)$ and AT-306 x G.Til- $1(\bar{X}=52.94)$ had below average stability. Among 40 crosses, 34 crosses considered as an unpredictable or unstable.

With 1000 seed weight in parent G.Til-1 $(\bar{X}=3.15)$ had average stability and widely adaptable to different environments. Two parents AT-341 ( $\overline{\mathrm{X}}=3.26)$ and AT-365 $(\bar{X}=3.05)$ had below average stability. Four crosses namely AT-306 x G.Til-1 ( $\overline{\mathrm{X}}=3.30$ ), AT-265 x RT-54 ( $\overline{\mathrm{X}}=3.19)$, AT-306 $\times$ AT$285(\bar{X}=3.13)$ and AT-307 $\mathrm{x} \quad \mathrm{RT}-54$ $(\bar{X}=3.08)$ had below average stability. For above average stability two crosses viz., AT$307 \times$ G.Til-1 ( $\overline{\mathrm{X}}=3.20)$ and AT-253 x AT$285(\bar{X}=3.14)$. Among $40 F_{1 S}, 28$ crosses considered as an unpredictable or unstable. 
None of the parents found which average responsive was and stable for seed yield per plant, but check G.Til-3 was stable over varying environments in seed yield per plant and its components. However, the parent IS209 was average responsive and stable for characters viz., number of capsules per leaf axil and number of seeds per capsule. This parent also had high per se performance for characters like days to maturity, height to first capsule and number of seeds per capsule. Likewise, another parent G.Til-10 had higher mean values for length of capsule with average responsive and stable over environments. This parent also had high per se performance for plant height, number of branch per plant, number of internodes per plant, length of capsule, width of capsule, number of capsules per plant, number of seeds per capsule and seed yield per plant. Similarly, parent Khadkala-S had high per se performance like days to flowering, days to maturity, plant height, number of branch per plant, number of internodes per plant, number of capsules per plant and number of capsules per leaf axil. The parent RT-54 was average responsive and stable number of capsules per leaf axil.

Among hybrids, two hybrids namely AT-322 $x$ G.Til-10 and AT-319 x AT-285 had below average stability which well adapted to favourable environments. Hybrid AT-322 x G.Til-10 also had high per se performance for number of capsules per plant and seed yield per plant. Likewise, hybrid AT-319 x AT-285 also had high per se performance 1000-seed weight. Only one hybrid i.e., Bhuva-2 x G.Til10 recorded high mean above average stability which showed greater tolerance to environmental changes; thereby genotypes would have specific adaptability to poor yielding environments. Three hybrids viz., Bhuva-2 x G.Til-1, IS-209 x RT-54 and IS209 x AT-285 with lower seed yield per plant as they exhibited regression coefficient around unity ( bi $\approx 1$ ) and non-significant $S^{2}$ di which indicated that these hybrid performed well under less favourable environmental conditions. The stability parameters for component traits revealed that several genotypes turned out to be stable for number of branches per plant (1), length of capsule (2), number of capsules per leaf axil (2), number of seeds per capsule (1) and 1000seed weight.

Further assessment of stability parameters across yield attributes revealed that the crosses AT-322 x G.Til-10 and AT-319 x AT-285 were found to be ideal for better management conditions, while the cross Bhuva- $2 \times$ G.Til10 was suitable for poor management conditions. It was observed that predictable and unpredictable environments was exhibited in hybrids for days flowering (33 and 7), days to maturity (22 and 18), plant height (10 and 30 ), height to first capsule (20 and 20), number of branches per plant (10 and 30), number of internodes per plant (24 and 16), length of capsule (11 and 29), width of capsule (19 and 21), number of capsules per plant (22 and 18), number of seeds per capsule (6 and 34), 1000-seed weight (12 28), oil content (25 and 15), protein content (12 and 28 ), seed yield per plant (10 and 30), biological yield per plant (4 and 36), harvest index (5 and 35), leaf area at 60 days ( 7 and 33) and chlorophyll contents at 60 days (13 and 27). The genotypes which are specifically adapted to better or either poor environments are due to adaptive plasticity or individual adaptability. The genotype may express different phenotypes in different environments, each of which being better adapted for the particular situation. This type of behavior has been regarded as adaptive plasticity (Mather, 1943), individual adaptability (Cook and Johnson, 1968) and individual buffering (Allard and Bradshaw, 1964) (Table 1-6). 
Table.1 Analysis of variance for stability for different characters in sesame

\begin{tabular}{|l|l|l|l|l|l|l|l|l|}
\hline Source & $\begin{array}{l}\text { Genotypes } \\
(\mathbf{G})\end{array}$ & $\begin{array}{l}\text { Environments } \\
(\mathbf{E})\end{array}$ & $\mathbf{G} \mathbf{x}$ E & $\begin{array}{l}\mathbf{E}+\mathbf{(}(\mathbf{G} \\
\mathbf{x ~ E )}\end{array}$ & $\begin{array}{l}\text { Environment } \\
(\mathbf{L i n} .)\end{array}$ & $\begin{array}{l}\text { G x E } \\
\text { (Linear) }\end{array}$ & $\begin{array}{l}\text { Pooled } \\
\text { Deviation }\end{array}$ & $\begin{array}{l}\text { Pooled } \\
\text { Error }\end{array}$ \\
\hline DF & $10.56^{* *}$ & $211.18^{* *}$ & 1.01 & $4.76^{* *}$ & $633.56^{* *}$ & $1.51^{* *}$ & $0.75^{* *}$ & 0.52 \\
\hline DM & $15.84^{* *}$ & $735.87^{* *}$ & 2.60 & $15.69^{* *}$ & $2207.60^{* *}$ & $2.25^{* *}$ & $2.72^{* *}$ & 1.11 \\
\hline PH & $223.27^{* *}$ & $1905.13^{* *}$ & $21.39^{* *}$ & $55.03^{* *}$ & $5715.40^{* *}$ & $41.88^{* *}$ & $10.95^{* *}$ & 2.40 \\
\hline HFC & $123.50^{* *}$ & $1711.20^{* *}$ & $12.59^{* *}$ & $42.93^{* *}$ & $5133.70^{* *}$ & $28.68^{* *}$ & $4.47^{* *}$ & 1.35 \\
\hline NBP & $2.20^{* *}$ & 0.06 & $0.11^{* *}$ & $0.11^{* *}$ & $0.17^{* *}$ & $0.07^{* *}$ & $0.13^{* *}$ & 0.01 \\
\hline NIP & $30.04^{* *}$ & $465.77^{* *}$ & $4.96^{* *}$ & $13.19^{* *}$ & $1397.32^{* *}$ & $6.95^{* *}$ & $3.89^{* *}$ & 1.05 \\
\hline LC & $0.13^{* *}$ & $0.07^{* *}$ & $0.01^{* *}$ & $0.02^{* *}$ & $0.22^{* *}$ & $0.04^{* *}$ & $0.01^{* *}$ & 0.00 \\
\hline WC & $0.01^{* *}$ & $0.01^{* *}$ & 0.00 & $0.00^{* *}$ & $0.01^{* *}$ & $0.00^{* *}$ & $0.00^{* *}$ & 0.00 \\
\hline NCP & $244.29^{* *}$ & $1742.51^{* *}$ & $53.06^{* *}$ & $83.23^{* *}$ & $5227.55^{* *}$ & $61.33^{* *}$ & $48.05^{* *}$ & 2.52 \\
\hline NCL & $0.18^{* *}$ & $0.23^{* *}$ & 0.02 & $0.03^{* *}$ & $0.70^{* *}$ & $0.04^{* *}$ & $0.01^{* *}$ & 0.01 \\
\hline NSC & $46.75^{* *}$ & $267.73^{* *}$ & $16.35^{* *}$ & $20.84^{* *}$ & $803.19^{* *}$ & $19.71^{* *}$ & $14.40^{* *}$ & 1.98 \\
\hline TW & $0.14^{* *}$ & $0.48^{* *}$ & $0.01^{* *}$ & $0.02^{* *}$ & $1.46^{* *}$ & $0.02^{* *}$ & $0.01^{* *}$ & 0.01 \\
\hline SY & $9.40^{* *}$ & $85.33^{* *}$ & $1.84^{* *}$ & $3.33^{* *}$ & $255.99^{* *}$ & $3.57^{* *}$ & $0.96^{* *}$ & 0.10 \\
\hline
\end{tabular}

*** Significant against pooled error at $5 \%$ and $1 \%$, respectively.

DF: Days flowering BR: Number of branch/plant

DM: Days to maturity IP: Number of internodes/ plant

PH: Plant height $(\mathrm{cm}) \quad$ LC: Length of capsule $(\mathrm{cm})$

HFC:Height to first capsule $(\mathrm{cm})$
NCP: Number of capsules/plant

CLA: Number of capsules/leaf axil

NSC: Number of seeds per capsule
TW: 1000 -seed weight $(\mathrm{g})$

CL: Capsule length $(\mathrm{cm})$

SY: Seed yield/plant $(\mathrm{g})$ 
Table.2 Parents and hybrids along with stability performance over different environments for seed yield and yield-contributing traits

\begin{tabular}{|c|c|c|c|c|c|c|c|c|c|c|c|c|c|}
\hline Character & DF & DM & PH & HFC & NBP & NIP & LC & WC & NCP & NCL & NSC & TW & SY \\
\hline \multirow{5}{*}{$\begin{array}{c}\text { Average } \\
\text { stability } \\
\text { (bi=1) }\end{array}$} & - & - & - & - & - & - & AT-319 & G.Til-3 & AT-319 & IS-209 & IS-209 & G.Til-1 & G.Til-3 \\
\hline & - & - & $\begin{array}{c}\text { Bhuva-2 } \\
\text { x AT-285 }\end{array}$ & $\begin{array}{c}\text { AT-341 x } \\
\text { RT-54 }\end{array}$ & $\begin{array}{c}\text { AT-307 } \\
\text { x G.Til- } \\
10\end{array}$ & $\begin{array}{l}\text { IS-209 x } \\
\text { G.Til-10 }\end{array}$ & G.Til-10 & $\begin{array}{l}\text { AT-265 x } \\
\text { G.Til-1 }\end{array}$ & $\begin{array}{l}\text { IS-209 x } \\
\text { AT-285 }\end{array}$ & RT-54 & - & - & AT-322 \\
\hline & - & - & - & - & - & - & $\begin{array}{c}\text { AT-253 x } \\
\text { G.Til-1 }\end{array}$ & $\begin{array}{c}\text { AT-253 x } \\
\text { G.Til-1 }\end{array}$ & - & $\begin{array}{c}\text { Khadkala- } \\
\text { S x AT- } \\
285\end{array}$ & - & - & - \\
\hline & - & - & -- & - & -- & - & $\begin{array}{c}\text { AT-265 x } \\
\text { RT-54 }\end{array}$ & $\begin{array}{c}\text { AT-306 x } \\
\text { G.Til-1 }\end{array}$ & - & $\begin{array}{c}\text { Khadkala- } \\
\text { Sx G.Til- } \\
1\end{array}$ & - & - & -- \\
\hline & - & - & - & - & - & - & $\begin{array}{l}\text { AT-253 x } \\
\text { G.Til-10 }\end{array}$ & $\begin{array}{l}\text { AT-307 x } \\
\text { AT-285 }\end{array}$ & - & $\begin{array}{c}\text { AT-265 x } \\
\text { AT-285 }\end{array}$ & - & - & - \\
\hline \multirow{5}{*}{$\begin{array}{c}\text { Below } \\
\text { average } \\
\text { stability } \\
(\text { bi }>1)\end{array}$} & $\begin{array}{c}\text { Khadkala- } \\
\text { S }\end{array}$ & & & & G.Til-3 & G.Til-10 & AT-265 & AT-285 & - & G.Til-1 & & AT-341 & \\
\hline & $\begin{array}{c}\text { Bhuva-2 x } \\
\text { AT-285 }\end{array}$ & $\begin{array}{l}\text { AT-322 x } \\
\text { RT-54 }\end{array}$ & $\begin{array}{l}\text { AT-253 x } \\
\text { G.Til-10 }\end{array}$ & $\begin{array}{c}\text { AT- } 253 x \\
\text { AT-285 }\end{array}$ & $\begin{array}{l}\text { IS-209 x } \\
\text { G.Til-10 }\end{array}$ & $\begin{array}{c}\text { Khadkala- } \\
\text { S x G.Til- } \\
10\end{array}$ & G.Til-3 & G.Til-1 & $\begin{array}{c}\text { AT-341 x } \\
\text { RT-54 }\end{array}$ & G.Til-3 & $\begin{array}{c}\text { AT-265 } \\
\text { x G.Til- } \\
10\end{array}$ & AT-365 & - \\
\hline & $\begin{array}{c}\text { Bhuva-2 x } \\
\text { RT-54 }\end{array}$ & $\begin{array}{c}\text { Bhuva-2 } \\
\text { x AT-285 }\end{array}$ & - & $\begin{array}{l}\text { AT-322 x } \\
\text { G.Til-1 }\end{array}$ & $\begin{array}{c}\text { AT-307 } \\
\text { x G.Til- } \\
10\end{array}$ & $\begin{array}{c}\text { AT-265 x } \\
\text { RT-54 }\end{array}$ & $\begin{array}{l}\text { AT-319 x } \\
\text { G.Til-1 }\end{array}$ & $\begin{array}{c}\text { AT- } 253 x \\
\text { AT- } 285\end{array}$ & - & $\begin{array}{c}\text { AT-265 x } \\
\text { RT-54 }\end{array}$ & $\begin{array}{c}\text { AT-306 } \\
\text { x G.Til- } \\
1\end{array}$ & $\begin{array}{c}\text { AT-306 } \\
\text { x G.Til- } \\
1\end{array}$ & $\begin{array}{c}\text { AT-322 } \\
\text { x G.Til- } \\
10\end{array}$ \\
\hline & $\begin{array}{c}\text { AT-253 x } \\
\text { RT-54 }\end{array}$ & $\begin{array}{l}\text { AT-265 x } \\
\text { AT-285 }\end{array}$ & - & $\begin{array}{c}\text { AT-341 x } \\
\text { AT-285 }\end{array}$ & - & $\begin{array}{c}\text { AT-265 x } \\
\text { G.Til-10 }\end{array}$ & $\begin{array}{c}\text { IS-209 x } \\
\text { AT-285 }\end{array}$ & $\begin{array}{l}\text { AT-319 x } \\
\text { G.Til-1 }\end{array}$ & - & $\begin{array}{c}\text { AT-307 x } \\
\text { AT-285 }\end{array}$ & - & $\begin{array}{l}\text { AT-265 } \\
\text { x RT-54 }\end{array}$ & $\begin{array}{c}\text { AT-319 } \\
\text { x AT- } \\
285\end{array}$ \\
\hline & - & - & - & $\begin{array}{c}\text { AT-319x } \\
\text { RT-54 }\end{array}$ & - & - & - & $\begin{array}{l}\text { Khadkala- } \\
\text { S x G.Til- } \\
1\end{array}$ & - & $\begin{array}{l}\text { AT-322 x } \\
\text { G.Til-1 }\end{array}$ & - & $\begin{array}{c}\text { AT-306 } \\
\text { x AT- } \\
285\end{array}$ & - \\
\hline \multirow{3}{*}{$\begin{array}{c}\text { Above } \\
\text { average } \\
\text { stability } \\
\text { (bi<1) }\end{array}$} & AT-319 & IS-209 & G.Til-10 & IS-209 & - & - & - & - & - & - & - & - & - \\
\hline & AT-341 & AT-285 & $\begin{array}{c}\text { Khadkala } \\
-S\end{array}$ & AT-253 & - & $\begin{array}{c}\text { AT-341 x } \\
\text { G.Til-10 }\end{array}$ & - & - & & $\begin{array}{c}\text { Bhuva-2 x } \\
\text { G.Til-1 }\end{array}$ & - & $\begin{array}{c}\text { AT-307 } \\
\text { x G.Til- } \\
1\end{array}$ & $\begin{array}{c}\text { Bhuva-2 } \\
\text { x } \\
\text { G.Til10 }\end{array}$ \\
\hline & G.Til-3 & AT- $-253 \mathrm{x}$ & AT-285 & AT-307 & - & Bhuva-2 $\mathrm{x}$ & - & - & Bhuva-2 & AT- $-265 x$ & - & AT-253 & - \\
\hline
\end{tabular}




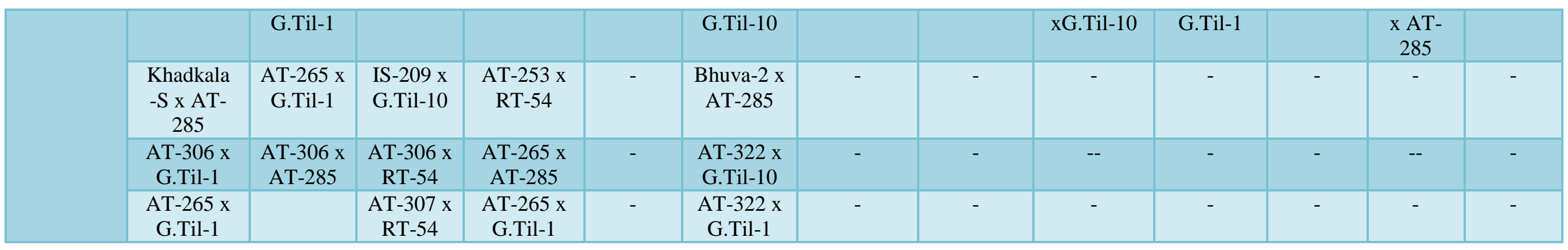

Table.3 Stability parameters for days to flowering, days to maturity and plant height $(\mathrm{cm})$ in sesame

\begin{tabular}{|c|c|c|c|c|c|c|c|c|c|c|}
\hline \multirow{2}{*}{$\begin{array}{l}\text { Sr. } \\
\text { No. }\end{array}$} & \multirow[t]{2}{*}{ Genotypes } & \multicolumn{3}{|c|}{ Days to flowering } & \multicolumn{3}{|c|}{ Days to maturity } & \multicolumn{3}{|c|}{ Plant height (cm) } \\
\hline & & $\overline{\mathrm{x}}$ & bi & $\mathbf{S}^{2} \mathrm{di}$ & $\overline{\mathrm{x}}$ & bi & $\mathbf{S}^{2} \mathrm{di}$ & $\overline{\mathrm{X}}$ & bi & $\mathbf{S}^{2} \mathrm{di}$ \\
\hline 1 & AT-253 & 39.42 & 0.26 & 0.13 & 84.67 & 0.38 & $1.54^{*}$ & 58.31 & $0.72 * *$ & $2.53 *$ \\
\hline 2 & AT-265 & 39.08 & $0.99 * *$ & 0.23 & 84.17 & 0.67 & $4.49 * *$ & 58.19 & 0.31 & $4.13^{*}$ \\
\hline 3 & AT-306 & 42.17 & $1.32 * *$ & 0.09 & 85.33 & $1.43^{* *}$ & 0.43 & 62.42 & $0.62 * *$ & 0.89 \\
\hline 4 & AT-307 & 41.00 & $1.25^{* *}$ & -0.08 & 83.92 & $1.3 * *$ & 0.31 & 59.93 & 0.32 & $6.61 * *$ \\
\hline 5 & AT-319 & 37.50 & $0.81 * *$ & 0.01 & 87.92 & $0.98 * *$ & 0.71 & 59.13 & $0.66^{* *}$ & $2.40^{*}$ \\
\hline 6 & AT-322 & 41.50 & $0.92 *$ & $0.97 *$ & 87.25 & $1.10^{* *}$ & -0.66 & 64.02 & 0.44 & $3.39 *$ \\
\hline 7 & AT-341 & 38.33 & $0.47 *$ & -0.08 & 84.08 & 0.42 & $6.15^{* *}$ & 81.16 & 0.37 & $3.45^{*}$ \\
\hline 8 & Bhuva-2 & 37.75 & $0.86^{*}$ & $0.76^{*}$ & 84.67 & $1.11 * *$ & 0.52 & 59.08 & $1.87 * *$ & $15.46 * *$ \\
\hline 9 & Khadkala-S & 37.08 & $1.40 * *$ & 0.28 & 84.08 & 0.99 & $11.58 * *$ & 80.78 & $0.47 *$ & 1.74 \\
\hline 10 & IS-209 & 38.92 & $0.97 * *$ & 0.02 & 83.08 & $0.87 * *$ & 0.39 & 58.39 & $0.95 *$ & $14.15^{* *}$ \\
\hline 11 & AT-285 & 39.00 & $1.24 * *$ & 0.42 & 82.75 & $0.78 * *$ & 0.47 & 67.80 & $0.56^{* *}$ & -1.09 \\
\hline 12 & G.Til-1 & 37.67 & 0.08 & $1.55^{*}$ & 84.58 & $0.95^{* *}$ & $1.28^{*}$ & 60.33 & $0.86^{* *}$ & $4.77 *$ \\
\hline 13 & G.Til-10 & 43.25 & $1.37 * *$ & -0.03 & 88.25 & $1.16^{* *}$ & -0.91 & 81.30 & $0.78 * *$ & 1.82 \\
\hline 14 & RT-54 & 41.42 & $0.96^{* *}$ & 0.03 & 84.83 & $1.04 *$ & $8.55 * *$ & 70.10 & $1.16^{* *}$ & $2.42 *$ \\
\hline 15 & AT-253 x AT-285 & 38.50 & $1.06^{* *}$ & -0.37 & 84.42 & $1.07 * *$ & 0.18 & 57.70 & $1.41 * *$ & $6.26 * *$ \\
\hline 16 & AT-253 x G.Til-1 & 38.83 & $1.40 * *$ & -0.39 & 83.83 & $0.67 * *$ & -0.95 & 61.00 & $0.72 * *$ & $4.04 *$ \\
\hline
\end{tabular}




\begin{tabular}{|c|c|c|c|c|c|c|c|c|c|c|}
\hline 17 & AT-253 x G.Til-10 & 39.33 & $0.39 *$ & -0.17 & 84.83 & $0.66^{* *}$ & -0.89 & 70.36 & $1.46^{* *}$ & -1.18 \\
\hline 18 & AT-253 x RT-54 & 37.50 & $1.29 * *$ & -0.39 & 82.25 & $1.05^{* *}$ & $1.91 *$ & 53.35 & 0.30 & $9.80^{* *}$ \\
\hline 19 & AT-265 x AT-285 & 37.42 & $1.22 * *$ & -0.37 & 81.67 & $1.00 * *$ & -0.65 & 60.31 & $0.97 * *$ & $5.04 *$ \\
\hline 20 & AT-265 x G.Til-1 & 36.67 & $0.73 * *$ & -0.42 & 82.00 & $0.83 * *$ & -0.05 & 61.04 & $0.87 * *$ & -0.30 \\
\hline 21 & AT-265 x G.Til-10 & 38.50 & $1.05^{* *}$ & 0.40 & 83.67 & $0.97 * *$ & $1.29 *$ & 66.64 & $0.86^{*}$ & $15.50 * *$ \\
\hline 22 & AT-265 x RT-54 & 37.33 & $1.02 * *$ & -0.02 & 82.08 & $0.93 * *$ & $1.61 *$ & 75.78 & 0.64 & $11.65^{* *}$ \\
\hline 23 & AT-306 × AT-285 & 37.33 & $1.13 * *$ & $0.74 *$ & 80.33 & $0.98 * *$ & 0.61 & 64.86 & $1.09 * *$ & $7.33 * *$ \\
\hline 24 & AT-306 x G.Til-1 & 36.42 & $0.55^{*}$ & 0.24 & 84.00 & $0.76^{* *}$ & -0.89 & 60.60 & $0.77 * *$ & $5.68 * *$ \\
\hline 25 & AT-306 x G.Til-10 & 41.17 & $1.08 * *$ & 0.07 & 87.33 & $1.32 * *$ & 0.52 & 79.58 & $1.31 * *$ & $6.63 * *$ \\
\hline 26 & AT-306 x RT-54 & 37.58 & $1.02 * *$ & -0.21 & 82.42 & $1.05 * *$ & -0.53 & 71.34 & $0.61 * *$ & 2.14 \\
\hline 27 & AT-307 x AT-285 & 37.50 & $1.66^{* *}$ & $1.47^{* *}$ & 83.08 & $1.16^{* *}$ & $3.1 * *$ & 66.28 & $0.89 * *$ & $3.32 *$ \\
\hline 28 & AT-307 x G.Til-1 & 38.25 & $1.65 * *$ & $1.16^{*}$ & 82.08 & $0.97 * *$ & $1.89 *$ & 66.14 & $0.68 * *$ & 0.33 \\
\hline 29 & AT-307 x G.Til-10 & 39.00 & 0.13 & $0.83 *$ & 85.75 & $1.22 * *$ & 0.29 & 69.68 & 0.80 & $16.47 * *$ \\
\hline 30 & AT-307 x RT-54 & 38.42 & $1.75^{* *}$ & -0.34 & 82.83 & $1.06^{* *}$ & -0.09 & 69.38 & $0.53 * *$ & -0.88 \\
\hline 31 & AT-319 x AT-285 & 38.33 & $1.45^{* *}$ & $0.95 *$ & 82.58 & $0.97 * *$ & $3.64 * *$ & 64.65 & $0.70 * *$ & 0.05 \\
\hline 32 & AT-319 x G.Til-1 & 36.92 & $0.71 * *$ & 0.32 & 82.42 & $0.90 * *$ & -0.66 & 58.24 & $2.25 * *$ & $5.95 * *$ \\
\hline 33 & AT-319 x G.Til-10 & 39.58 & $0.79 * *$ & -0.35 & 85.83 & $1.28 * *$ & -0.08 & 67.33 & $0.54 *$ & $5.28 *$ \\
\hline 34 & AT-319 x RT-54 & 37.50 & $1.03 * *$ & -0.27 & 82.67 & $0.82 * *$ & $2.58 *$ & 56.84 & $2.85 * *$ & -1.68 \\
\hline 35 & AT-322 × AT-285 & 37.42 & $0.99 * *$ & 0.23 & 82.00 & $0.95^{* *}$ & $1.32 *$ & 59.37 & $1.91 * *$ & -1.54 \\
\hline 36 & AT-322 x G.Til-1 & 39.25 & $1.07 * *$ & $0.84 *$ & 83.25 & $0.60 * *$ & 0.98 & 58.44 & $1.22 * *$ & $3.81^{*}$ \\
\hline 37 & AT-322 x G.Til-10 & 40.58 & $1.42 * *$ & $0.97 *$ & 86.00 & $1.42 * *$ & $8.29 * *$ & 67.80 & $1.16^{* *}$ & $13.28 * *$ \\
\hline 38 & AT-322 x RT-54 & 37.67 & $0.93^{*}$ & $1.24 * *$ & 80.92 & $1.14 * *$ & -0.28 & 60.73 & $1.95 * *$ & $18.25^{* *}$ \\
\hline 39 & AT-341 x AT-285 & 38.42 & 0.68 & $1.77 * *$ & 81.00 & 0.52 & $2.42 *$ & 73.93 & 0.21 & $6.39 * *$ \\
\hline 40 & AT-341 x G.Til-1 & 37.08 & $0.97 * *$ & $0.73 *$ & 81.58 & $1.17 * *$ & $2.60 *$ & 63.05 & 0.12 & $9.47 * *$ \\
\hline 41 & AT-341 x G.Til-10 & 39.50 & $0.50 * *$ & -0.33 & 84.58 & $0.69 * *$ & 0.09 & 78.75 & $0.91 *$ & $13.05 * *$ \\
\hline 42 & AT-341 x RT-54 & 37.33 & $0.73 * *$ & 0.21 & 82.42 & $0.99 * *$ & $3.62 * *$ & 67.74 & 0.12 & $5.40 *$ \\
\hline 43 & Bhuva-2 x AT-285 & 36.75 & $1.34 * *$ & -0.16 & 81.33 & $1.29 * *$ & 0.46 & 71.16 & 0.12 & -0.96 \\
\hline 44 & Bhuva-2 x G.Til-1 & 39.33 & $0.87 * *$ & 0.21 & 82.50 & $1.14 * *$ & $1.30 *$ & 61.11 & $2.00 *$ & $78.76^{* * *}$ \\
\hline 45 & Bhuva-2 x G.Til-10 & 41.25 & 0.50 & $1.02 *$ & 88.58 & $0.93 * *$ & 0.96 & 78.79 & $1.06 * *$ & $13.75 * *$ \\
\hline 46 & Bhuva-2 x RT-54 & 37.33 & $1.30 * *$ & -0.37 & 82.83 & $1.18 * *$ & -0.86 & 56.17 & $2.07 * *$ & $7.28 * *$ \\
\hline
\end{tabular}




\begin{tabular}{|r|l|r|r|r|r|r|r|r|r|r|r|r|}
\hline $\mathbf{4 7}$ & Khadkala-S x AT-285 & 36.17 & $0.99 * *$ & -0.07 & 82.42 & $1.05 * *$ & $2.33 *$ & 61.07 & 0.56 & $10.09 * *$ \\
\hline $\mathbf{4 8}$ & Khadkala-S x G.Til-1 & 38.08 & $1.36 * *$ & -0.21 & 83.50 & $1.14 * *$ & $2.21 *$ & 64.14 & $1.27 *$ & $34.51 * *$ \\
\hline $\mathbf{4 9}$ & Khadkala-S x G.Til-10 & 41.33 & $1.02 * *$ & -0.08 & 87.17 & $1.13 * *$ & $3.78 * *$ & 73.56 & $2.36 * *$ & $13.04 * *$ \\
\hline $\mathbf{5 0}$ & Khadkala-S x RT-54 & 38.92 & $0.63 * *$ & 0.03 & 84.00 & $1.02 * *$ & $1.95 *$ & 68.42 & $0.93 *$ & $14.33 * *$ \\
\hline $\mathbf{5 1}$ & IS-209 x AT-285 & 38.08 & $1.43 * *$ & -0.19 & 82.92 & $1.40 * *$ & 0.12 & 63.67 & $1.21 * *$ & $11.76 * *$ \\
\hline $\mathbf{5 2}$ & IS-209 x G.Til-1 & 37.08 & $1.25 * *$ & -0.26 & 84.17 & $1.00 * *$ & -0.56 & 57.89 & $2.68 * *$ \\
\hline $\mathbf{5 3}$ & IS-209 x G.Til-10 & 41.25 & $1.07 * *$ & 0.45 & 88.83 & $1.37 * *$ & -0.67 & 80.58 & $0.55 * *$ & -1.49 \\
\hline $\mathbf{5 4}$ & IS-209 x RT-54 & 38.67 & $0.97 * *$ & -0.40 & 83.17 & 0.82 & $6.21 * *$ & 56.33 & 0.92 & $46.98 * *$ \\
\hline $\mathbf{5 5}$ & G.Til-2 & 41.17 & $1.01 * *$ & 0.22 & 84.42 & $1.24 * *$ & $5.69 * *$ & 70.52 & $1.21 * *$ & $7.26 * *$ \\
\hline $\mathbf{5 6}$ & G.Til-3 & 38.67 & $0.97 * *$ & -0.40 & 83.75 & $0.92 * *$ & 0.40 & 67.13 & $1.12 * *$ & $6.62 * *$ \\
\hline & Mean & $\mathbf{3 8 . 7 0}$ & & & $\mathbf{8 3 . 8 7}$ & & $\mathbf{6 5 . 7 5}$ & \\
\hline
\end{tabular}

$*$,** Significant at 5 and $1 \%$ levels, respectively.

Table.4 Stability parameters for height to first capsule, number of branches /plant and number of internodes /plant in sesame

\begin{tabular}{|c|c|c|c|c|c|c|c|c|c|c|}
\hline \multirow{2}{*}{$\begin{array}{l}\text { Sr. } \\
\text { No. }\end{array}$} & \multirow[t]{2}{*}{ Genotypes } & \multicolumn{3}{|c|}{ Height to first capsule } & \multicolumn{3}{|c|}{ Number of branches per plant } & \multicolumn{3}{|c|}{ Number of internodes per plant } \\
\hline & & $\overline{\mathrm{X}}$ & bi & $\mathrm{S}^{2} \mathrm{di}$ & $\overline{\mathrm{X}}$ & bi & $\mathrm{S}^{2} \mathrm{di}$ & $\overline{\mathrm{x}}$ & bi & $\mathrm{S}^{2} \mathrm{di}$ \\
\hline 2 & AT-265 & 21.49 & $0.34 * *$ & 0.08 & 2.15 & -3.06 & 0.00 & 17.01 & $0.96^{* *}$ & 0.91 \\
\hline 4 & AT-307 & 21.35 & $0.36^{* *}$ & 0.17 & 2.23 & 1.68 & -0.01 & 17.45 & 0.43 & $4.29 * *$ \\
\hline 5 & AT-319 & 21.58 & $0.33 * *$ & -0.89 & 2.55 & 4.05 & $0.13 * *$ & 18.16 & 0.88 & $5.51 * *$ \\
\hline 6 & AT-322 & 23.74 & $0.49 * *$ & -0.94 & 2.31 & -2.55 & $0.05^{* *}$ & 16.68 & $1.42 * *$ & 0.48 \\
\hline 9 & Khadkala-S & 39.11 & $0.83^{* *}$ & -0.76 & 3.07 & $-4.69 * *$ & -0.01 & 23.12 & 0.54 & $1.80^{*}$ \\
\hline 10 & IS-209 & 18.88 & $0.57 * *$ & 0.52 & 2.40 & -0.08 & $0.21 * *$ & 20.68 & 0.46 & $1.01 *$ \\
\hline 11 & AT-285 & 26.36 & $0.48 * *$ & 0.08 & 2.43 & 1.33 & $0.04 * *$ & 20.71 & $0.89 * *$ & 0.12 \\
\hline 12 & G.Til-1 & 22.88 & $0.68 * *$ & $3.08 *$ & 2.27 & $-11.88 * *$ & $0.04 * *$ & 18.90 & 0.77 & $2.96^{* *}$ \\
\hline 13 & G.Til-10 & 40.48 & $0.87 * *$ & 0.19 & 4.26 & 1.15 & $0.28 * *$ & 24.89 & $1.18^{* *}$ & 0.16 \\
\hline
\end{tabular}




\begin{tabular}{|c|c|c|c|c|c|c|c|c|c|c|}
\hline 14 & RT-54 & 29.83 & $1.44 * *$ & -0.75 & 4.60 & $-10.15 * *$ & -0.01 & 24.76 & 0.53 & $2.92 * *$ \\
\hline 15 & AT $-253 \times$ AT -285 & 17.86 & $1.23 * *$ & -0.13 & 2.49 & -0.49 & $0.11 * *$ & 19.33 & $1.21 *$ & $8.37 * *$ \\
\hline 17 & AT -253 x G.Til-10 & 27.14 & $1.63^{* *}$ & -1.17 & 5.28 & -5.02 & $0.08^{* *}$ & 24.68 & $1.31 * *$ & $2.42 *$ \\
\hline 19 & AT-265 x AT-285 & 18.50 & $0.45^{* *}$ & 0.32 & 2.59 & 2.50 & 0.00 & 21.40 & $1.07 * *$ & $2.24 *$ \\
\hline 20 & AT-265 x G.Til-1 & 24.73 & $0.91 * *$ & -0.31 & 2.61 & $8.12 *$ & $0.02 *$ & 19.41 & $1.57 * *$ & -0.28 \\
\hline 21 & AT-265 x G.Til-10 & 26.75 & $1.09 * *$ & 0.90 & 3.68 & 0.37 & $0.09 * *$ & 22.15 & $1.35 * *$ & -0.25 \\
\hline 24 & AT-306 x G.Til-1 & 29.53 & $0.74 * *$ & $1.89 *$ & 2.38 & -0.06 & $0.05^{* *}$ & 19.13 & $1.97 * *$ & 0.37 \\
\hline 25 & AT-306 x G.Til-10 & 33.58 & $2.13 * *$ & -0.29 & 4.48 & 2.89 & $0.16^{* *}$ & 26.15 & $1.24 * *$ & $3.08 * *$ \\
\hline 26 & AT-306 x RT-54 & 31.33 & 0.51 & $7.86^{* *}$ & 2.43 & $11.54 * *$ & $0.01^{*}$ & 21.49 & $1.63 * *$ & $8.27 * *$ \\
\hline 27 & AT-307 x AT-285 & 28.45 & $0.81 * *$ & 0.76 & 2.89 & -0.36 & $0.08 * *$ & 21.01 & $1.32 * *$ & $1.09 *$ \\
\hline 28 & AT-307 x G.Til-1 & 26.75 & $0.69 * *$ & 0.16 & 2.53 & -0.39 & $0.08 * *$ & 20.32 & $2.45^{* *}$ & 0.95 \\
\hline 29 & AT-307 x G.Til-10 & 28.54 & $1.12 * *$ & -1.16 & 3.06 & -3.57 & 0.01 & 25.01 & $1.01^{*}$ & $3.47 * *$ \\
\hline 34 & AT-319 x RT-54 & 21.93 & $2.00 * *$ & -0.55 & 2.57 & 11.45 & $0.11 * *$ & 16.53 & $0.91 * *$ & -0.54 \\
\hline 35 & AT-322 x AT-285 & 22.75 & $1.59 * *$ & -0.27 & 2.34 & 2.76 & $0.14 * *$ & 21.67 & $1.07 * *$ & -0.21 \\
\hline 36 & AT-322 x G.Til-1 & 20.92 & $1.32 * *$ & 0.19 & 2.11 & 4.61 & $0.07 * *$ & 23.08 & $0.45^{*}$ & 0.00 \\
\hline 37 & AT-322 x G.Til-10 & 25.66 & $1.36^{* *}$ & 0.53 & 3.76 & 1.70 & $0.22 * *$ & 23.86 & $0.77 * *$ & -0.29 \\
\hline 38 & AT-322 x RT-54 & 22.63 & $1.71 * *$ & $6.76^{* *}$ & 2.52 & -0.83 & $0.01 *$ & 21.28 & $0.61 * *$ & -0.51 \\
\hline 39 & AT-341 x AT-285 & 21.54 & $1.62 * *$ & 1.07 & 2.10 & $2.92 * *$ & -0.01 & 22.06 & 0.37 & $1.54 *$ \\
\hline 40 & AT-341 x G.Til-1 & 25.26 & 0.17 & $1.80^{*}$ & 2.46 & -4.17 & $0.15^{* *}$ & 17.95 & $0.63 * *$ & -0.07 \\
\hline 41 & AT-341 x G.Til-10 & 31.31 & $1.18^{*}$ & $19.17 * *$ & 3.12 & -5.97 & $0.09 * *$ & 26.01 & $0.51^{*}$ & 0.60 \\
\hline 42 & AT-341 x RT-54 & 27.09 & 0.23 & -0.02 & 2.62 & 3.51 & 0.01 & 19.35 & $1.19 * *$ & $2.72 * *$ \\
\hline 43 & Bhuva-2 x AT-285 & 26.19 & $0.74 * *$ & $1.37 *$ & 2.72 & $6.04 * *$ & 0.00 & 24.56 & $0.42 *$ & -0.12 \\
\hline
\end{tabular}




\begin{tabular}{|c|c|c|c|c|c|c|c|c|c|c|}
\hline 44 & Bhuva-2 x G.Til-1 & 21.44 & $1.64 * *$ & $17.02 * *$ & 2.68 & -1.13 & -0.01 & 18.86 & $1.1 * *$ & -0.12 \\
\hline 45 & Bhuva-2 x G.Til-10 & 33.12 & $1.72 * *$ & $2.10 *$ & 4.08 & 1.97 & $0.13 * *$ & 25.83 & $0.61 *$ & 0.84 \\
\hline 46 & Bhuva-2 x RT-54 & 19.76 & $1.41 * *$ & $3.09 *$ & 2.81 & 4.55 & $0.08 * *$ & 17.39 & 0.55 & $3.49 * *$ \\
\hline 47 & Khadkala-S x AT-285 & 22.56 & 0.53 & $6.34 * *$ & 2.54 & 2.26 & $0.24 * *$ & 18.24 & 0.44 & $1.69 *$ \\
\hline 48 & Khadkala-S x G.Til-1 & 23.08 & $0.90 *$ & $11.24 * *$ & 2.74 & 0.92 & $0.44 * *$ & 19.70 & 0.71 & $2.44 *$ \\
\hline 49 & Khadkala-S x G.Til-10 & 32.08 & $2.56 * *$ & 1.09 & 3.16 & -6.67 & $0.09 * *$ & 24.52 & $1.44 * *$ & -0.98 \\
\hline 50 & Khadkala-S x RT-54 & 26.65 & $0.85 *$ & $12.15 * *$ & 2.27 & 5.94 & $0.27 * *$ & 21.24 & 0.67 & $9.27 * *$ \\
\hline 51 & IS-209 x AT-285 & 22.01 & $1.16 * *$ & -0.18 & 2.34 & -0.98 & $0.44 * *$ & 21.36 & 0.53 & $5.05 * *$ \\
\hline 52 & IS-209 x G.Til-1 & 22.06 & $1.91 * *$ & $5.53 * *$ & 2.26 & -0.65 & $0.06 * *$ & 20.60 & $1.14 * *$ & $2.89 * *$ \\
\hline 53 & IS-209 x G.Til-10 & 35.62 & $1.38 * *$ & $18.04 * *$ & 3.86 & $7.92 * *$ & -0.01 & 26.82 & 0.05 & -0.60 \\
\hline 54 & IS-209 x RT-54 & 19.72 & $0.89 * *$ & $5.52 * *$ & 2.43 & 11.68 & $0.44 * *$ & 19.01 & 0.03 & $7.92 * *$ \\
\hline 55 & G.Til-2 & 28.46 & $0.88 * *$ & $1.67 *$ & 2.53 & -0.45 & -0.01 & 22.47 & 1.38 & $18.53 * *$ \\
\hline \multirow[t]{2}{*}{56} & G.Til-3 & 25.52 & $0.92 * *$ & 0.84 & 3.04 & $5.21 *$ & 0.00 & 22.56 & $0.69 *$ & $1.88 *$ \\
\hline & Mean & 25.83 & & & 2.84 & & & 21.04 & & \\
\hline
\end{tabular}

*** Significant at 5 and $1 \%$ levels, respectively

Table.5 Stability parameters for length of capsule $(\mathrm{cm})$, width of capsule $(\mathrm{cm})$ and number of capsules per plant in sesame

\begin{tabular}{|c|c|c|c|c|c|c|c|c|c|c|}
\hline \multirow{2}{*}{$\begin{array}{l}\text { Sr. } \\
\text { No. }\end{array}$} & \multirow[t]{2}{*}{ Genotypes } & \multicolumn{3}{|c|}{ Length of capsule (cm) } & \multicolumn{3}{|c|}{ Width of capsule (cm) } & \multicolumn{3}{|c|}{ Number of capsules per plant } \\
\hline & & $\overline{\mathrm{X}}$ & bi & $\mathbf{S}^{2} \mathbf{d i}$ & $\bar{x}$ & bi & $\mathbf{S}^{2} \mathrm{di}$ & $\overline{\mathrm{X}}$ & bi & $\mathbf{S}^{2} \mathbf{d i}$ \\
\hline 2 & AT-265 & 2.68 & $4.08^{* *}$ & 0.00 & 0.76 & -0.17 & 0.00 & 26.68 & 0.55 & $15.16^{* *}$ \\
\hline 4 & AT-307 & 2.38 & 0.51 & $0.00^{*}$ & 0.75 & 2.40 & $0.001 * *$ & 27.01 & 0.72 & $35.6 * *$ \\
\hline 5 & AT-319 & 2.80 & 0.82 & 0.00 & 0.77 & -0.62 & $0.001 * *$ & 24.25 & 0.14 & 1.99 \\
\hline 6 & AT-322 & 2.26 & -0.26 & $0.03 * *$ & 0.74 & -0.33 & $0.00 *$ & 24.04 & $0.38^{*}$ & 0.70 \\
\hline 9 & Khadkala-S & 2.39 & 0.38 & $0.01 * *$ & 0.75 & 0.73 & $0.00 *$ & 33.54 & $1.22 *$ & $26.27 * *$ \\
\hline 10 & IS-209 & 2.39 & $-1.79 *$ & 0.00 & 0.76 & -0.22 & $0.00 *$ & 31.63 & 0.39 & $26.69 * *$ \\
\hline
\end{tabular}




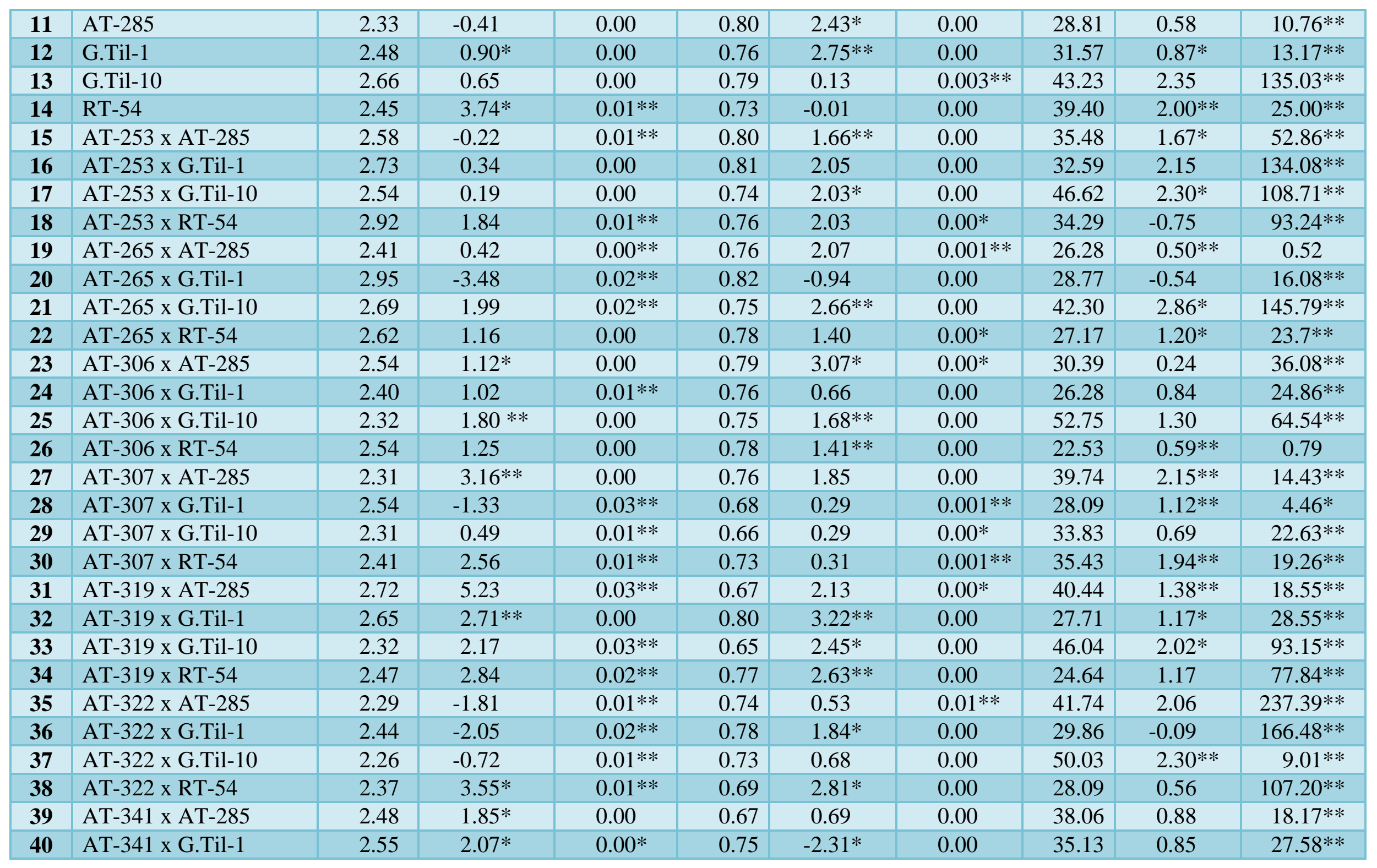




\begin{tabular}{|c|c|c|c|c|c|c|c|c|c|c|}
\hline 41 & AT-341 x G.Til-10 & 2.33 & 2.06 & $0.02 * *$ & 0.67 & 0.69 & $0.001 * *$ & 52.39 & $2.37 * *$ & $23.75 * *$ \\
\hline 42 & AT-341 x RT-54 & 2.47 & $2.77 *$ & $0.00 * *$ & 0.68 & 1.53 & $0.001 * *$ & 34.83 & $1.39 * *$ & -0.62 \\
\hline 43 & Bhuva-2 x AT-285 & 2.29 & $3.29 *$ & $0.01 * *$ & 0.69 & 2.36 & $0.00 *$ & 35.45 & 0.87 & $68.94 * *$ \\
\hline 44 & Bhuva-2 x G.Til-1 & 2.23 & 0.28 & 0.00 & 0.73 & 0.17 & $0.00 *$ & 38.31 & -0.56 & $44.14 * *$ \\
\hline 45 & Bhuva-2 x G.Til-10 & 2.50 & $2.76 * *$ & 0.00 & 0.69 & 0.38 & $0.001 * *$ & 43.35 & $0.27 *$ & -1.35 \\
\hline 46 & Bhuva-2 x RT-54 & 2.32 & -0.58 & $0.02 * *$ & 0.72 & $2.18 * *$ & 0.00 & 27.25 & $1.58 * *$ & $3.00 *$ \\
\hline 47 & Khadkala-S x AT-285 & 2.35 & -1.09 & $0.02 * *$ & 0.69 & 1.89 & $0.00 *$ & 29.20 & 0.30 & $29.75 * *$ \\
\hline 48 & Khadkala-S x G.Til-1 & 2.83 & 3.43 & $0.01 * *$ & 0.79 & $1.92 * *$ & 0.000 & 36.21 & 1.14 & $100.73 * *$ \\
\hline 49 & Khadkala-S x G.Til-10 & 2.52 & 2.00 & $0.00 * *$ & 0.73 & -0.15 & $0.00 *$ & 35.42 & 1.53 & $79.32 * *$ \\
\hline 50 & Khadkala-S x RT-54 & 2.56 & -2.77 & $0.02 * *$ & 0.75 & -2.36 & $0.001 * *$ & 24.89 & -0.26 & $21.76 * *$ \\
\hline 51 & IS-209 x AT-285 & 2.79 & $-2.55^{*}$ & $0.00 *$ & 0.78 & 0.02 & $0.001 * *$ & 22.93 & 0.26 & -0.38 \\
\hline 52 & IS-209 x G.Til-1 & 2.59 & -0.59 & $0.01 * *$ & 0.78 & -0.85 & $0.001 * *$ & 30.83 & $0.81 * *$ & $4.31 *$ \\
\hline 53 & IS-209 x G.Til-10 & 2.65 & 1.78 & $0.00 *$ & 0.77 & -1.01 & $0.001 * *$ & 44.06 & $1.45^{* *}$ & $17.25 * *$ \\
\hline 54 & IS-209 x RT-54 & 2.75 & $3.69 *$ & $0.01 * *$ & 0.74 & -0.6 & $0.001 * *$ & 26.80 & 0.48 & $3.27 *$ \\
\hline 55 & G.Til-2 & 2.32 & $3.54 *$ & $0.01 * *$ & 0.68 & 2.34 & $0.001 * *$ & 35.90 & 0.22 & $299.04 * *$ \\
\hline \multirow[t]{2}{*}{56} & G.Til-3 & 2.90 & $1.01 * *$ & 0.00 & 0.78 & 0.12 & 0.00 & 33.43 & $1.39 * *$ & $7.54 * *$ \\
\hline & Mean & 2.51 & & & 0.74 & & & 33.92 & & \\
\hline
\end{tabular}

*** Significant at 5 and $1 \%$ levels, respectively

Table.6 Stability parameters for number of capsules/leaf axil, number of seeds/capsule,1000-seed weight and seed yield per plant in sesame

\begin{tabular}{|c|c|c|c|c|c|c|c|c|c|c|c|c|c|}
\hline \multirow{2}{*}{$\begin{array}{l}\text { Sr. } \\
\text { No. }\end{array}$} & \multirow[t]{2}{*}{ Genotypes } & \multicolumn{3}{|c|}{ No. of capsules/ leaf axil } & \multicolumn{3}{|c|}{ Number of seeds/capsule } & \multicolumn{3}{|c|}{ 1000-seed weight (g) } & \multicolumn{3}{|c|}{ Seed yield per plant (g) } \\
\hline & & $\overline{\mathrm{X}}$ & bi & $\mathbf{S}^{2} \mathrm{di}$ & $\overline{\mathrm{x}}$ & bi & $S^{2} d i$ & $\overline{\mathrm{x}}$ & bi & $\mathbf{S}^{2} \mathbf{d i}$ & $\overline{\mathrm{X}}$ & $\mathbf{B i}$ & $\mathbf{S}^{2} \mathbf{d i}$ \\
\hline 1 & AT-253 & 1.38 & $5.04 * *$ & $0.01 *$ & 56.68 & 2.22 & $21.97 * *$ & 3.26 & $2.28 *$ & $0.02 * *$ & 4.87 & $1.06^{* *}$ & -0.10 \\
\hline 2 & AT-265 & 1.23 & $3.54 * *$ & $0.01 *$ & 49.61 & $2.77 * *$ & $6.12 * *$ & 3.05 & $1.29 * *$ & 0.00 & 3.89 & 0.52 & $0.69 * *$ \\
\hline 3 & AT-306 & 1.13 & $2.34 * *$ & 0.00 & 50.63 & 1.33 & $11.69 * *$ & 3.13 & $2.12 * *$ & $0.00 *$ & 4.01 & $0.83 * *$ & -0.08 \\
\hline 4 & AT-307 & 1.22 & $3.29 * *$ & -0.01 & 48.89 & 0.94 & $3.95 *$ & 3.50 & 0.22 & $0.01 * *$ & 4.66 & 0.58 & $2.07 * *$ \\
\hline 5 & AT-319 & 1.15 & 1.02 & 0.00 & 55.36 & $2.47 * *$ & $7.85^{* *}$ & 3.35 & $1.14 * *$ & $0.00^{*}$ & 4.30 & $0.32 * *$ & -0.06 \\
\hline 6 & AT-322 & 1.02 & 0.26 & 0.00 & 47.17 & -0.52 & 1.86 & 3.16 & $2.00 * *$ & $0.00 *$ & 3.54 & 0.38 & $0.12 *$ \\
\hline 7 & AT-341 & 1.05 & -0.12 & 0.00 & 51.88 & 1.23 & $7.65^{* *}$ & 3.26 & $1.81^{* *}$ & 0.00 & 7.89 & $1.27 * *$ & $0.41 * *$ \\
\hline
\end{tabular}




\begin{tabular}{|c|c|c|c|c|c|c|c|c|c|c|c|c|c|}
\hline 8 & Bhuva-2 & 1.27 & 0.55 & 0.00 & 52.22 & 0.38 & $6.32 * *$ & 3.05 & -0.45 & $0.0^{*}$ & 5.00 & 0.42 & $0.13 *$ \\
\hline 9 & Khadkala-S & 1.93 & -0.68 & $0.04 * *$ & 48.07 & -1.11 & $4.15^{*}$ & 3.08 & -0.52 & $0.01^{* *}$ & 4.68 & 0.55 & $0.26 * *$ \\
\hline 10 & IS-209 & 1.37 & 1.34 & 0.00 & 53.81 & 0.28 & 2.23 & 2.97 & 0.28 & $0.01 * *$ & 4.83 & 0.20 & $0.20 *$ \\
\hline 11 & AT-285 & 1.13 & $-1.79 * *$ & 0.00 & 52.61 & -0.46 & $12.19 * *$ & 2.86 & 0.00 & 0.00 & 4.29 & $0.48 *$ & $0.14 *$ \\
\hline 12 & G.Til-1 & 1.33 & $3.10^{* *}$ & 0.00 & 53.24 & 0.23 & $16.44 * *$ & 3.15 & -0.13 & $0.00 *$ & 5.07 & $0.92 * *$ & $0.11^{*}$ \\
\hline 13 & G.Til-10 & 1.07 & 0.48 & 0.00 & 59.48 & 2.14 & $38.77 * *$ & 2.89 & $-1.63^{* *}$ & $0.00 *$ & 7.28 & $2.47 * *$ & $2.39 * *$ \\
\hline 14 & RT-54 & 1.35 & -0.70 & 0.00 & 55.38 & 2.65 & $30.46 * *$ & 3.04 & $1.00^{* *}$ & 0.00 & 6.56 & $2.51 * *$ & $0.44 * *$ \\
\hline 15 & AT-253 x AT-285 & 1.12 & 1.32 & 0.00 & 49.51 & -0.10 & $43.62 * *$ & 3.14 & $0.86 * *$ & 0.00 & 5.28 & $1.36 *$ & $1.40 * *$ \\
\hline 16 & AT-253 x G.Til-1 & 1.43 & 0.45 & $0.03 * *$ & 50.88 & 0.20 & $71.98 * *$ & 3.11 & $1.54 * *$ & 0.00 & 4.91 & $1.79 *$ & $2.98 * *$ \\
\hline 17 & AT-253 x G.Til-10 & 1.28 & -0.08 & $0.01 *$ & 62.25 & $3.25^{* *}$ & $4.08^{*}$ & 2.68 & 1.11 & $0.01 * *$ & 7.77 & $2.48 * *$ & $2.99 * *$ \\
\hline 18 & AT-253 x RT-54 & 1.15 & $1.98 * *$ & 0.00 & 54.53 & 1.42 & $8.79 * *$ & 3.20 & $1.59 * *$ & $0.01 * *$ & 5.72 & -0.10 & $4.96 * *$ \\
\hline 19 & AT-265 x AT-285 & 1.47 & -0.07 & 0.00 & 52.24 & $1.27 * *$ & -1.17 & 3.08 & 0.81 & $0.02 * *$ & 3.97 & $0.43 * *$ & -0.01 \\
\hline 20 & AT-265 x G.Til-1 & 1.77 & $-2.30 *$ & $0.01 *$ & 51.07 & $1.19 * *$ & 0.44 & 3.29 & $1.67 *$ & $0.01 * *$ & 4.52 & -0.22 & $0.14 *$ \\
\hline 21 & AT-265 x G.Til-10 & 1.27 & 1.65 & $0.02 * *$ & 56.73 & $1.96 * *$ & 0.95 & 3.08 & $1.91 * *$ & 0.00 & 7.44 & $3.29 * *$ & $2.96 * *$ \\
\hline 22 & AT-265 x RT-54 & 1.35 & $3.08 * *$ & $0.01 *$ & 50.47 & 1.29 & $6.55 * *$ & 3.19 & $1.12 * *$ & 0.00 & 4.22 & $1.21 * *$ & $0.45^{* *}$ \\
\hline 23 & AT-306 x AT-285 & 1.23 & $1.13 *$ & 0.00 & 57.32 & 1.70 & $12.58 * *$ & 3.13 & $2.09 * *$ & 0.00 & 5.20 & 0.58 & $0.74 * *$ \\
\hline 24 & AT-306 x G.Til-1 & 1.12 & $2.08 * *$ & 0.00 & 52.94 & $1.97 * *$ & 0.86 & 3.30 & $1.46^{* *}$ & 0.00 & 4.28 & $0.79 *$ & $0.53 * *$ \\
\hline 25 & AT-306 x G.Til-10 & 1.10 & 0.10 & 0.00 & 55.40 & 2.71 & $59.40 * *$ & 2.84 & -0.03 & $0.00^{* *}$ & 8.01 & $2.01 * *$ & $0.30 * *$ \\
\hline 26 & AT-306 x RT-54 & 1.18 & 0.43 & $0.01 *$ & 50.73 & 0.15 & $3.56^{*}$ & 2.71 & $1.78^{*}$ & $0.02 * *$ & 2.93 & $0.42 *$ & 0.05 \\
\hline 27 & AT-307 x AT-285 & 1.35 & $4.59 * *$ & 0.01 & 51.34 & 1.14 & $45.08 * *$ & 3.03 & $1.59 * *$ & 0.00 & 6.11 & $2.05 * *$ & $1.72 * *$ \\
\hline 28 & AT-307 x G.Til-1 & 1.23 & $2.85^{* *}$ & $0.01 *$ & 52.43 & 1.32 & $14.30 * *$ & 3.20 & $0.64 * *$ & 0.00 & 4.55 & $1.00 * *$ & $0.43 * *$ \\
\hline 29 & AT-307 x G.Til-10 & 1.08 & 1.36 & $0.01 *$ & 56.23 & 1.50 & $6.58 * *$ & 2.69 & $1.38^{*}$ & $0.01^{* *}$ & 4.88 & $0.81 * *$ & $0.26 * *$ \\
\hline 30 & AT-307 x RT-54 & 1.57 & $2.03 *$ & $0.01 *$ & 48.57 & 1.16 & $6.75 * *$ & 3.08 & $2.79 * *$ & 0.00 & 5.13 & $1.56^{* *}$ & $0.26 * *$ \\
\hline 31 & AT-319 x AT-285 & 1.07 & 0.55 & 0.00 & 52.42 & $1.59 *$ & $7.07 * *$ & 3.28 & $1.83^{*}$ & $0.01 * *$ & 6.73 & $1.55^{* *}$ & 0.05 \\
\hline 32 & AT-319 x G.Til-1 & 1.17 & -0.17 & 0.00 & 54.63 & 1.47 & $10.27 * *$ & 2.85 & $1.27 * *$ & 0.00 & 4.06 & $0.78 *$ & $0.46^{* *}$ \\
\hline 33 & AT-319 x G.Til-10 & 1.08 & $0.95 * *$ & -0.01 & 62.37 & 3.77 & $52.13 * *$ & 3.12 & 0.69 & $0.02 * *$ & 9.00 & $3.50 * *$ & $2.93 * *$ \\
\hline 34 & AT-319 x RT-54 & 1.27 & $2.75^{*}$ & $0.01 *$ & 51.10 & $1.96 * *$ & -1.86 & 3.11 & $1.53 * *$ & $0.00 *$ & 3.77 & 0.92 & $1.37 * *$ \\
\hline 35 & AT-322 x AT-285 & 1.05 & $0.91 * *$ & -0.01 & 49.80 & $0.85 * *$ & -0.67 & 3.27 & 0.39 & $0.03 * *$ & 6.48 & 1.50 & $6.21 * *$ \\
\hline 36 & AT-322 x G.Til-1 & 1.50 & $3.40^{* *}$ & 0.00 & 47.90 & 0.04 & $2.71 *$ & 2.70 & -0.01 & $0.00 * *$ & 3.66 & -0.25 & $2.03 * *$ \\
\hline 37 & AT-322 x G.Til-10 & 1.18 & $-1.50^{* *}$ & -0.01 & 55.47 & $2.84 * *$ & $2.64 *$ & 3.16 & $1.70 * *$ & $0.01 * *$ & 8.73 & $2.98 * *$ & 0.07 \\
\hline
\end{tabular}




\begin{tabular}{|c|c|c|c|c|c|c|c|c|c|c|c|c|c|}
\hline 38 & AT-322 x RT-54 & 1.22 & -0.01 & $0.03 * *$ & 50.37 & 1.53 & $15.60 * *$ & 2.70 & 0.24 & $0.01 * *$ & 3.63 & 0.73 & $1.34 * *$ \\
\hline 39 & AT-341 x AT-285 & 1.20 & $1.72 * *$ & 0.00 & 52.66 & $-1.79^{*}$ & $6.12 * *$ & 2.84 & $-0.70^{* *}$ & 0.00 & 5.39 & 0.14 & $0.12 *$ \\
\hline 40 & AT-341 x G.Til-1 & 1.35 & $3.29 *$ & $0.02 * *$ & 51.48 & -1.54 & $15.03 * *$ & 2.97 & 0.70 & $0.00 *$ & 5.08 & 0.47 & $0.19 *$ \\
\hline 41 & AT-341 x G.Til-10 & 1.08 & $0.81 *$ & 0.00 & 54.04 & 0.20 & $14.81 * *$ & 3.28 & $1.47 * *$ & $0.00 *$ & 8.87 & $1.90 * *$ & $0.5^{* *}$ \\
\hline 42 & AT-341 x RT-54 & 1.17 & $1.82 * *$ & 0.00 & 51.19 & 0.94 & $3.42 *$ & 2.91 & 1.23 & $0.02 * *$ & 4.90 & $1.14 * *$ & $0.14 *$ \\
\hline 43 & Bhuva-2 x AT-285 & 1.38 & -1.43 & $0.08 * *$ & 49.95 & 0.52 & $5.45 * *$ & 2.90 & $1.07 *$ & $0.00 * *$ & 4.88 & 0.75 & $1.36^{* *}$ \\
\hline 44 & Bhuva-2 x G.Til-1 & 1.63 & $-1.13^{*}$ & 0.00 & 49.05 & 0.79 & $14.90 * *$ & 2.87 & $1.86 * *$ & $0.00 *$ & 5.06 & -0.21 & 0.00 \\
\hline 45 & Bhuva-2 x G.Til-10 & 1.33 & 2.13 & $0.01^{*}$ & 52.77 & 1.51 & $8.83 * *$ & 2.96 & $0.67 *$ & $0.00 *$ & 6.49 & $0.43 * *$ & 0.01 \\
\hline 46 & Bhuva-2 x RT-54 & 1.17 & $-2.37 * *$ & 0.00 & 50.13 & 0.81 & $3.69^{*}$ & 2.81 & $0.78 *$ & $0.00 *$ & 3.66 & $0.92 * *$ & 0.08 \\
\hline 47 & Khadkala-Sx AT-285 & 1.73 & -0.55 & 0.00 & 49.34 & $2.40 * *$ & $5.27 * *$ & 2.92 & 1.01 & $0.02 * *$ & 3.94 & 0.24 & $0.19 *$ \\
\hline 48 & Khadkala-S x G.Til-1 & 1.67 & 0.55 & 0.01 & 51.98 & 0.91 & $12.54 * *$ & 3.13 & $2.34 * *$ & $0.00 *$ & 5.70 & $1.53 * *$ & $1.41 * *$ \\
\hline 49 & Khadkala-S xG.Til10 & 1.58 & -0.46 & $0.06 * *$ & 53.10 & 0.66 & $9.22 * *$ & 2.93 & 0.96 & $0.00 * *$ & 5.30 & $1.50 * *$ & $0.93 * *$ \\
\hline 50 & Khadkala-S x RT-54 & 1.75 & 1.29 & $0.02 * *$ & 45.62 & -0.77 & $12.49 * *$ & 3.05 & -0.14 & $0.04 * *$ & 3.27 & $-0.48 * *$ & 0.03 \\
\hline 51 & IS-209 x AT-285 & 1.17 & 0.24 & 0.00 & 47.33 & 0.82 & $7.57 * *$ & 2.76 & $1.25 * *$ & 0.00 & 2.87 & 0.18 & 0.05 \\
\hline 52 & IS-209 x G.Til-1 & 1.27 & 2.27 & $0.04 * *$ & 50.77 & -0.40 & $3.47 *$ & 3.39 & $1.56 * *$ & $0.00 * *$ & 5.08 & 0.59 & $0.31 * *$ \\
\hline 53 & IS-209 x G.Til-10 & 1.20 & 0.62 & 0.00 & 54.60 & 0.11 & $10.95 * *$ & 3.02 & $1.63 * *$ & 0.00 & 7.02 & $1.34 *$ & $1.15^{* *}$ \\
\hline 54 & IS-209 x RT-54 & 1.63 & -1.48 & $0.02 * *$ & 50.13 & -0.36 & $10.42 * *$ & 2.88 & $-1.66^{* *}$ & $0.01 * *$ & 3.63 & 0.05 & -0.04 \\
\hline 55 & G.Til-2 & 1.23 & 0.65 & 0.00 & 49.48 & 0.67 & $4.49 *$ & 3.03 & $1.40^{*}$ & $0.01 * *$ & 5.93 & $0.72 * *$ & $0.17 *$ \\
\hline 56 & G.Til-3 & 1.53 & $2.89 * *$ & 0.00 & 54.46 & -0.19 & $2.96^{*}$ & 3.20 & $1.26 *$ & $0.01 * *$ & 7.10 & $1.10 * *$ & -0.02 \\
\hline & Mean & 30 & & & 52.32 & & & 3.04 & & & 5.28 & & \\
\hline
\end{tabular}


On the basis of mean performance, regression coefficient and deviation from regression values, some of the genotypes have been identified with stability of performance under favourable and unfavorable environments in terms of seed yield (Table 2) two hybrids AT322 x G.Til-10 and AT-319 x AT-285 had below average stability which well adapted to favourable environments. The parents, AT319 for length of capsule, G.Til-3 for width of capsule, AT-319 for number of capsule per plant, IS-209 for number of seed per capsule, G.Til-1 for 1000 seed weight and G.Til-3 for seed yield per plant were found average stable for environments. Hence, these parents may be used in the breeding programmes aimed at improving seed yield and yield components, in addition to incorporation of phenotypic stability for the traits in sesame.

\section{References}

Allard, R. W. and Bradshaw, A. D. (1964). Implications of genotype environmental interactions in applied plant breeding. Crop Sci., 4: 503-508.

Anonymous, (2016). Status Paper on Oilseeds. Oilseeds Division, Department of Agriculture and Cooperation, Ministry of Agriculture, Government of India, New Delhi.

Bhat, K.V.; Babrekar, P.P and Lakhanpaul. S. (1999). Study of genetic diversity in Indian and exotic sesame (Sesamum indicum L.) germplasm using random amplified olymorphic DNA (RAPD) markers. Euphytica., 110:21-33.

Bedigian, D. and Harlan, J. R. (1986). Evidence for cultivation of sesame in the ancient world. Econ Bot., 40 (2):137-154.

Breese, E.L. (1969). The measurement and significance of genotype $\mathrm{x}$ environment interactions in grasses. Heredity., 24:2744.

Chaudhari, G. B.; Naik, M. R.; Anarase, S. A. and. Ban, Y.G. (2015b). Genotype x Environment interaction for yield and yield components in sesame (Sesamum indicum L.). Elec. J. Pl. Breed., 6 (1): 218-224.

Cook, S. A. and Johnson, M. P. (1968). Adaptation to heterogeneous environments. I. Variation in Ranunculus flammula L. Evolution., 22:496-516.

Eberhart, S. A. and Russell, W. A. (1966). Stability parameter for comparing varieties. Crop Science. 6: 36-40.

Comstock, R. E. and Moll, R. H. (1963). Genotype-environment interactions. In: "Statistical Genetics and Plant Breeding" NAS-NRC Publ.982, Washington D.C. pp. 164-196.

Jatsara, D.S., Paroda, R.S. (1980): Phenotype adaptability of characters resulted to productivity in wheat cultivars. Indian J. Genet. 40:132-139

Khan, M. A.; Nawaz, N.; Rashid, A.; Tahira, Amjad, M. and Tariq, M. (2015). Genotype environment interaction and stability analysis for seed yield in sesame (Sesamum indicum L.). Sky J. Agric. Re. 4 (6): 110 - 113.

Kumar, N.; Tikka, S. B. S.; Dagla, M. C.; Bhagirath ram and Meenaa, H. P. (2013). Genotypic adaptability for seed yield and physiological traits in sesame (sesamum indicum L.) The Bioscan., 8 (4): 1503-1509.

Kumaresan, D. and Nadarajan, N. (2010). Genotype $\mathrm{x}$ environment interactions for seed yield and its components in sesame (Sesamum indicum L.). Elec. J. Pl. Breed., 1 (4): 1126-1132.

Mather, K. (1943). Polygenic inheritance and natural selection. Biol. Rev., 18: 32-In: $\mathrm{G} \times \mathrm{E}$ interaction, its measurement and significance in Plant Breeding. (Eds. Verma, M.M. and Gill, K.S.). PAU Bull., 1: 7-18.

Mali, R. D.; Yamgar, S.; Kharade, M. R. and 
Ghodake, M. K. (2015). Estimatation of stability parameter for yield and yield contributing characters in sesame (Sesamum indicum L.). J. Agric. Vet. Sci., 8 (7): 2319-2372.

Najeeb, U.; Mirza, M. Y.; Jilani, G.; Mubashir, A. K. and Zhou, W. J. (2012) Sesame. In: Gupta SK (ed),Technological innovations in major world oil crops, vol 1. Springer, New York, pp 131-145.

Panse, V.G. and Sukhatme, P.V. (1985). Statistical Methods for Agricultural Workers. Indian Council of Agricultural Research, New Delhi.

Patil, V. S.; Wadikar, P. B.; Wadikar, S. K.; Patil, C.; H. V. Patil H.V Sudrik, B. P. Sudrikb.P. (2015). Stability analysis of yield and yield components in sesame (Sesamum indicum L.). J. Soils and Crops., 25 (1): 92-99.

Paroda, R.S. and Hayes, J.D. (1971). An investigation of genotype - environment interactions on rate of ear emergence in spring barley. Heredity., 26: 157-175.

Ram, B. B.; Kumar, K.; E. V. D, Shastri and Solanki, Z. S. (2018b). Phenotypic stability of hybrids and parents in sesame (Sesamum indicum L.). Intern. J. Agri. Sci., 10 (10): 6131-6134.

Raikwar, R. S. (2016). Stability for grain yield and its contributing traits in sesame (Sesamum indicum L.). Elec. J. Pl. Breed., 7 (4): 1033-1039.

Samuel, C. J. A.; Hill, J.; Breese, E.L. and Davis, A. (1970). Assessing and predicting environmental response in Lolium Pereene J. Agric. Sci. Comb., 75: 1-9.

Suvarna; Manjunath, M. H.; Nehru, S. D. and Manjunath, A. (2011). Stability analysis of sesame varieties during early kharif. Indian J.Agric.Res., 45 (3): 244-248.

Weiss, E. A., (1983). Oilseed Crops., Longman, New York.

\section{How to cite this article:}

Parmar, R.S., V.P. Chovatia, H.R. Barad, G.K. Sapara and Rajivkumar. 2018. G×E Interaction for Seed Yield and Its Components Traits in Summer Sesame (Sesamum indicum L). Int.J.Curr.Microbiol.App.Sci. 7(12): 1921-1941. doi: https://doi.org/10.20546/ijcmas.2018.712.223 